\title{
The Effect Of Quality Product, Brand Image, And Price Towards A Purchase Decision Of J.Co Donuts \& Coffee In Tangerang
}

\author{
Waseso Segoro $^{1 *}$, Debi Nurlita ${ }^{2}$ \\ ${ }^{1,2}$ Faculty of Economics, Gunadarma University, Jakarta, Indonesia \\ ${ }^{*}$ Corresponding Author: \\ Email:waseso@staff.gunadarma.ac.id
}

\begin{abstract}
.
The development of the business world today is very fast, making business people have to compete with each other to attract consumers. One promising business is a business in the food sector such as donuts. Donuts are a type of food that is popular in Indonesian society. At present there are many donut outlets that stand in the center of the crowd. One of them is J.CO Donuts \& Coffee in Tangerang which is the donut and coffee shop with the most consumers. With friendly prices and the brand image owned by J.CO Donuts \& Coffee, consumers do not hesitate to buy their products. This study aims to determine the quality of the product, brand image and price of J.CO Donuts \& Coffee purchasing decisions. The data used are primary data derived from questionnaires distributed online. Sampling using accidental sampling method with a sample size of 100 people. With the analysis technique used to analyze the influence of the variables in this study is to use the validity test, reliability test, classical assumption test, multiple regression analysis, and hypothesis testing using SPSS version 20.The result of this study is that there is a partial influence between variables of product quality, brand image and price on purchasing decisions. And the variables of product quality, brand image and price simultaneously influence purchasing decisions.
\end{abstract}

Keywords : Product Quality, Brand Image, Price, Purchase Decision.

\section{INTRODUCTION}

The development of the business world today is very fast, making business people have to compete with each other to attract consumers regarding quality of the product, brand image and price. Business people are required to be more creative and innovative in order to survive amid increasingly fierce competition. One promising business is a business in the food sector such as donuts. Donuts are a type of food that is popular in Indonesian society. Currently in Tangerang, there are many donut outlets that are standing in various centers of the crowd, such as J.CO Donuts and Coffee. This study aims to determine the effect of product quality, brand image and price to the J.CO Donuts \& Coffee purchasing decisions.

\section{LITERATURE REVIEW}

\subsection{Product Quality}

According to Kotler and Keller (2009), a product is anything that can be offered to the market to satisfy a desire or need, including physical goods, services, experiences, events, people, places, property, organizations, information and ideas. In other words, a product is a producer 's subjective understanding of something in an attempt to meet consumer needs and wants. The product is the focal point of a company's marketing activities because the product is the company's product that can be offered to the market and is ultimately a tool to achieve the company's goals.

\subsection{Brand Image}

According to Kotler and Armstrong (2008), a brand is a name, term, sign, symbol or design, or a combination of these that shows the product or service identity of a single seller or group of sellers and differentiates that product from competitors' products. 


\subsection{Price}

According to Laksana (2008), price is the amount of money needed to exchange various combinations of products and services, thus a price must be associated with a variety of goods and services that will ultimately be the same as something, namely products and services.

\subsection{Buying Decision}

According to Kotler and Keller (2012), purchasing decisions are the stage in the buyer's decision-making process where consumers will actually buy.

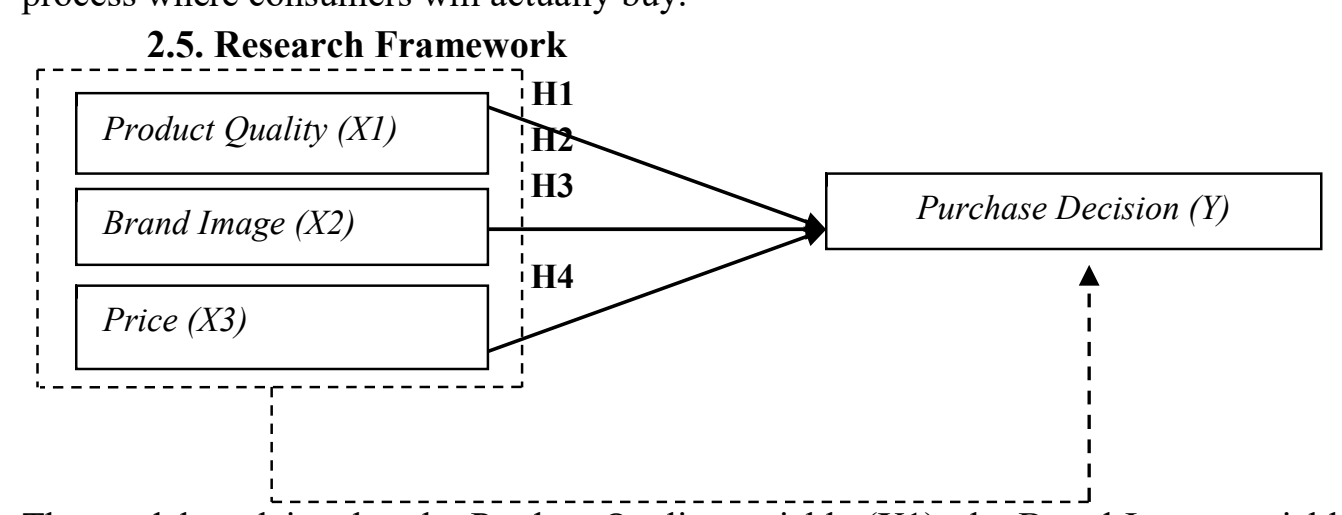

The model explains that the Product Quality variable (X1), the Brand Image variable (X2), and the Price (X3) variable affect the purchasing decisions at J.CO Donuts \& Coffee (Y).

\subsection{Hypothesis}

H1 : Product quality variables partially affect purchasing decisions.

H2 : The brand image variable partially affects purchasing decisions.

H3 : Price variable partially affects purchasing decisions.

H4 : The variables of Product Quality, Brand Image and Price simultaneously influence purchasing decisions.

\section{RESEARCH METHOD}

\subsection{Population and Samples}

The population size in this study is not known, so that to determine the size of the population in the study is very much and cannot be known with certainty, this is because there is no record of consumers who come. The sampling technique in this study using accidental sampling. According to Siregar (2013), accidental sampling is a sampling technique based on chance, that is, anyone who happens to meet the researcher can be used as a sample, if it is considered that the person who happened to be met is suitable as a data source.

\subsection{Data Collection}

In data collection carried out using primary data. Primary data is by distributing questionnaires to respondents. The questionnaire was distributed via google form to J.CO Donuts \& Coffee consumer respondents to get a number of respondents' answers.

\subsection{Data Analysis}

The analysis was carried out using the help of a computer program, namely SPSS (Statistical Package For Socoal Science) version 20, the analysis tools used in this study were: validity test, reliability test, normality test, multicolinearity test, heterocedastity test, multiple linear regression test, test $\mathrm{T}, \mathrm{F}$ test, and $\mathrm{R}^{2}$ test.

\section{RESULTS AND DISCUSSION}

\begin{tabular}{|l|l|l|l|}
\hline \multirow{2}{*}{ Hypothesis } & Test Result & \multirow{2}{*}{ Mean } \\
\cline { 2 - 3 } & T Test (Partial Test) & Conclusion & Influenced \\
$\begin{array}{l}\mathbf{H}_{1} \quad \text { Product } \\
\text { Quality }\end{array}$ & $\begin{array}{l}\mathrm{T}_{\text {count }}>\mathrm{T}_{\text {table }} \\
(2,142>1,984) \\
\text { Significant level: } 0,035<\end{array}$ & $\begin{array}{l}\text { The better the quality of the product } \\
\text { provided, the purchase decision at J.CO } \\
\text { Donuts \& Coffee will increase. }\end{array}$ \\
\hline
\end{tabular}




\begin{tabular}{|l|l|l|l|}
\hline & 0,05 & & \\
\hline $\begin{array}{l}\mathbf{H}_{2} \text { Brand } \\
\text { Image }\end{array}$ & $\begin{array}{l}\mathrm{T}_{\text {count }}>\mathrm{T}_{\text {table }}(2,427>1,984) \\
\text { Significant level: } \\
0,17<0,05\end{array}$ & Influenced & $\begin{array}{l}\text { Positive Brand Image by giving } \\
\text { distinctive characteristics / distinctive } \\
\text { differences with competitor products. } \\
\text { Then purchase decision will } \\
\text { increase at J.CO }\end{array}$ \\
\hline $\mathbf{H}_{3}$ Price & $\begin{array}{l}\mathrm{T}_{\text {count }}>\mathrm{T}_{\text {table }} \\
(5,379>1,984) \\
\text { Significant level: } \\
0,00<0,05\end{array}$ & Influenced & $\begin{array}{l}\text { The more affordable the price given by } \\
\text { J.CO Donuts \& Coffee, the more } \\
\text { purchasing decisions there will be. }\end{array}$ \\
\hline $\begin{array}{l}\text { H4 Quality } \\
\text { Product, } \\
\text { Brand Image } \\
\text { and Price }\end{array}$ & $\begin{array}{l}\mathrm{F}_{\text {count }}>\mathrm{F}_{\text {table }} \\
(25,621>2,70) \\
\text { Significant level: } \\
0,00<0,05\end{array}$ & Influenced & $\begin{array}{l}\text { If Product Quality, Brand Image and } \\
\text { Price have a positive effect together, } \\
\text { the purchasing decision at J.Co Donuts } \\
\text { \& Coffee will increase. }\end{array}$ \\
\hline
\end{tabular}

\section{CONCLUSION}

Based on the results of the analysis that has been done, it can be concluded that:

5.1. The Product Quality variable has a positive and significant effect on the purchasing decision of J.CO Donuts \& Coffee

5.2. The Brand Image variable has a positive and significant effect on the purchasing decision of J.CO Donuts \& Coffee

5.3. The Price variable has a positive and significant effect on the purchase decision of J.CO Donuts \& Coffee 5.4. The variables of Product Quality, Brand Image and Price simultaneously have a positive and significant effect on the purchasing decision of J.CO Donuts \& Coffee.

\section{SUGGESTIONS}

The company must be able to maintain or even improve the J.CO Donuts \& Coffee purchasing decisions. Therefore, companies should pay more attention to the factors that can improve purchasing decisions from product quality, brand image and price. The company is also expected to be able to present new innovations in its products to maintain business competition and maintain good product quality.

\section{REFERENCES}

[1] Armstrong \& Kotler. 2004. Prinsip - Prinsip Pemasaran Edisi 12, Jilid 1. Jakarta: Erlangga.

[2] Fajar, Laksana, 2008. Manajemen Pemasaran. Yogyakarta: Penerbit Graha Ilmu.

[3] Kotler, dan Keller. 2012. Manajemen Pemasaran. Edisi 12. Jakarta: Erlangga.

[4] Kotler, dan Keller. 2009. Manajemen Pemasaran. Jilid I. Edisi 13. Jakarta: Erlangga.

[5] Kotler, Philip \& Keller. 2008. Manajemen Pemasaran. Edisi 13. Jllid 1. Jakarta:Erlangga.

[6] Kotler \& Armstrong. 2008. Prinsip - Prinsip Pemasaran. Jilid 1 dan 2. Edisi 12. Jakarta: Erlangga

[7] Kotler, Philip, dan Gary Armstrong 2012. Prinsip-prinsip Pemasaran. Edisi 13. Jilid 1. Erlangga : Jakarta.

[8] Siregar. 2013. Manajemen Pemasaran. Bandung: CV Yrama Widya. 